\title{
A Comparison between Generation X and Generation Y in Terms of Individual Innovativeness Behavior: The Case of Turkish Health Professionals
}

\author{
Sema Yigit ${ }^{1} \&$ Kadir Aksay ${ }^{2}$ \\ ${ }^{1}$ Unye Faculty of Economics and Administrative Sciences, Ordu University, Ordu, Turkey \\ ${ }^{2}$ Fatsa Faculty of Marine Sciences, Ordu University, Ordu, Turkey \\ Correspondence: Sema Yigit, Unye Faculty of Economics and Administrative Sciences, Department of Business \\ Administration, Ordu University, Ordu, Turkey. E-mail: sema.yigit@odu.edu.tr
}

Received: February 19, 2015

Accepted: March 4, 2015

Online Published: March 10, 2015

doi:10.5430/ijba.v6n2p106

URL: http://dx.doi.org/10.5430/ijba.v6n2p106

\begin{abstract}
Today the criterion of innovation has become a paradigm for all institutions to maintain their success. Innovation is essential for service industry as well as production industry. It is the individual that is in the center of innovation, which can be defined as the difference between a good idea and a good product. The innovative work behavior of individuals is an area that needs to be scrutinized in terms of innovativeness. Because innovation directly effects the quality of life, it has a significant role in the health sector.

In this perspective, this study aims to identify the innovativeness level of individuals working in health industry where innovation is of significance; to identify the differences of innovativeness levels between generations; and to identify the relationship between individuals' perception of whether the institution they work have learning orientation and their level of innovativeness.

The data in this study, which specifically addresses health institutions with their increasing role in the information society, were gathered from the three private hospitals in Black Sea Region in Turkey. 274 health professionals working in those three private hospitals and accepting to take part in the study formed the sample group of the study.

The results of the study show that there is a difference of innovative behavior scores between the participants coming from Generation $\mathrm{X}$ and $\mathrm{Y}$. This difference indicates that Generation $\mathrm{X}$ is more innovative. Moreover, majority of the participants from Generation $X$ are physicians. In this respect, it can be noted that in terms of innovative behavior the difference between physicians and other health professionals (professional difference) is more significant than the difference between generations.
\end{abstract}

Keywords: generation X and Y, individual innovativeness, organizational learning, health industry, Turkey

\section{Introduction}

Health sector is in sectors that are dense in technology and information. As innovations and developments in health sector directly effects human life and quality of life, innovation plays a vital role in health sector, different from other sectors (TÜSİAD, 2011). The portfolio of innovation in health sector consists mostly of product/service and process innovations. While product/service innovation offers a new treatment service, process innovation focuses on the internal processes in hospitals and covers the improvement of clinical examination techniques (Schultz, Zippel-Schultz, \& Salomo, 2012).

Health professionals have an important role in the efficient application of innovation. In this role, individuals' innovativeness characteristics is one of the most important factors that create the difference. As an individual characteristic, innovativeness can be related to taking risks, being open new experiences or age (Goldsmith \& Foxall, 2003). Indeed, it would not be completely wrong to note that age factor is relatively more important, taking into consideration its impact on other factors. 
Individuals belonging to different generations of age have different experiences, different views, different habits and different work style. Although there are five different groups of generation in the literature, workforce can be regarded to be formed by individuals from Baby Boomers, Generation X and Generation Y, considering the fact that majority of the members of the traditionalist generation (those born before 1943) and generation $\mathrm{Z}$ (those born after 2000) are not in the working life. As for the generational structure of the workforce in Turkey, those from the generation of baby boomers form $10 \%$ of the workforce, Generation X forms about $44 \%$, and Generation Y, which is the last generation employed, forms about $46 \%$ of the workforce (TÜIK, 2014). Thus, the total rate of generations $\mathrm{X}$ and $\mathrm{Y}$ in total workforce is $90 \%$.

There are many studies in the literature investigating the impact of generational differences on workplaces. Differences between generation in terms of values about profession (Meriac, Woehr, \& Banister, 2010; Cogin, 2012; Schullery, 2013); organizational commitment (Benson \& Brown, 2011; Dixon, Mercado, \& Knowles, 2013), career paths (Lyons, Schweitzer, \& Ng, 2015), job satisfaction (Benson \& Brown, 2011; Young, Sturts, Ross, \& Kim, 2013), motivation factors (Montana \& Petit, 2008) intention to leave (Benson \& Brown, 2011) have been intensively studied. However, to our knowledge, no study has investigated the possible differences between generations in terms of innovative behaviors.

In this study, individual innovativeness characteristics of Generation Y, the largest group in the business world, were scrutinized in comparison with Generation X. Within this line, comparative analyses were made between Generation $\mathrm{X}$ and Generation $\mathrm{Y}$ by determining the profiles of those generations' innovative behaviors.

\section{Background}

\subsection{Generational Diversity}

The concept of generation is studied by social scientists from various perspectives. While the concept of generation can be described as a group of individuals that are related to each other or have mutual characteristics, it can also be handled as a stage of life or a historical period (Kertzer, 1983). However, generation is generally regarded as the differences between the age groups of certain time periods (Pilcher, 1994). Generation is a concept which refers to a group of individuals that have similar birth years and experiences, and whose thoughts, attitudes, values, beliefs and behaviors are effected by various factors, and who effects those factors in turn (Kupperschmidt, 2000; Johnson \& Johnson, 2010). These factors are a result of political, economic or cultural structure of the period they live (Guillot-Soulez \& Soulez, 2014). Generations are majorly influenced by the historical events individuals encounter until they become adults. As a result of the power and impact of these shared events, each generation constructs unique structure of belief, attitude and behavior (Giancola, 2006) and a unique identity that shapes the feelings that they have for the authority and organizations (Gürsoy, Maier, \& Chi, 2008).

Although there is consensus on the names of the first two of these generations, it is seen that there are various names for Generation Y. A similar dispute exists in the classification of the age groups that define the generations (Smola \& Sutton, 2002). In this study, age groups were determined based on Gürsoy et al.'s (2008) classification.

Baby boomers: It consists of individuals born in 1943-1960 and those born during the World War II or during the population growth after the war. Individuals from this generation are 7.5\% of Turkey's population (TÜİK, 2013).

Generation X (Gen X): These are the member of the generation who were born in 1961-1980 and are about 26\% of Turkey's population. Generation $X$ is the first generation to grow up with personal computers in the age of information; however, they were intensively affected by the social and economic disorder, and thus they are less optimistic than the previous generation but they believe in themselves (Sayers, 2007).

Generation Y (Gen Y): This is the generation of individuals who were born in 1981-2000 and it is about 33\% of Turkey's population. It is also called Millennials, Generation Me, Echo Boomers and Nexters (Twenge, 2010; Parry \& Urwin, 2011). The members of this generation are the children of the previous generation who increased the quality of their lives thanks to the industrial evolution in the 70s, and have a good standard of life in a good environment (Puybaraud, Russell, MsEwan, \& Leussink, 2010).

Table 1 shows the professional characteristics of Generations X and Y, who are about $90 \%$ of the workforce in Turkey. 
Table 1. Generations $\mathrm{X}$ and $\mathrm{Y}$ in terms of their professional characteristics

\begin{tabular}{|c|c|c|}
\hline & Professional Characteristics & References \\
\hline \multirow{5}{*}{ 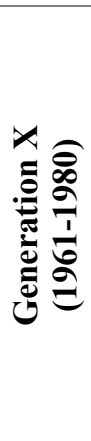 } & They work to live. & Gürsoy, Maier, \& Chi, 2008 \\
\hline & $\begin{array}{l}\text { They are easy-going, independent, and creative; they may } \\
\text { object to the system; they are suspicious and impatient. }\end{array}$ & $\begin{array}{l}\text { Zemke, Raines, \& Filipczak, } \\
2013\end{array}$ \\
\hline & $\begin{array}{l}\text { They believe in themselves; they do not like being watched. } \\
\text { They would rather show loyalty to their occupation and those } \\
\text { they work with than organization. Although they take their } \\
\text { occupation seriously, they do not rely on a single organization } \\
\text { for their career. }\end{array}$ & $\begin{array}{l}\text { Shragay \& Tziner, 2011; } \\
\text { Jorgensen, } 2003\end{array}$ \\
\hline & $\begin{array}{l}\text { They try to have a balance between work and life. They have a } \\
\text { hunger for learning; they can do many things at the same time. }\end{array}$ & $\begin{array}{l}\text { Kupperschmidt, 1998; Bova \& } \\
\text { Kroth, } 2001\end{array}$ \\
\hline & They are reluctant to have a leadership role. & Jorgensen, 2003 \\
\hline \multirow{5}{*}{ 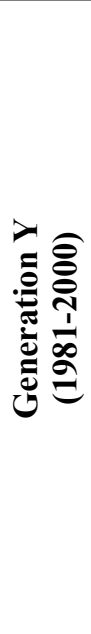 } & $\begin{array}{l}\text { They interrogate. They would like to know all about what the } \\
\text { organization demands from them, what career opportunities } \\
\text { they have and what the rewards are. }\end{array}$ & 1,2005 \\
\hline & $\begin{array}{l}\text { They like to take responsibility and prove themselves. They } \\
\text { expect respect rather than money. They have strong feeling for } \\
\text { success. }\end{array}$ & $\begin{array}{l}\text { Martin, 2005; Morton, 2002; } \\
\text { Lowe, Levitt, \& Wilson, 2008; } \\
\text { Gürsoy, Maier, \& Chi, 2008; } \\
\text { Eisner, 2005 }\end{array}$ \\
\hline & $\begin{array}{l}\text { They care about the meaning of the occupation. They can do } \\
\text { jobs from various fields at the same time. }\end{array}$ & $\begin{array}{l}\text { Eisner, 2005; Bennett, Pitt, \& } \\
\text { Price, } 2012 .\end{array}$ \\
\hline & $\begin{array}{l}\text { They do not hesitate to leave the job when they are not happy } \\
\text { with. Moreover, they would like to work in organizations that } \\
\text { are innovative, creative, energetic and environmentally } \\
\text { friendly. }\end{array}$ & $\begin{array}{l}\text { Lowe, Levitt, \& Wilson, 2008; } \\
\text { Deloitte, } 2014\end{array}$ \\
\hline & $\begin{array}{l}\text { They care about family and they would like to have a balance } \\
\text { between work and life. However, they are willing to work } \\
\text { hard to make progress in the early stages of their career. }\end{array}$ & $\begin{array}{l}\text { Gürsoy, Maier, \& Chi, 2008; } \\
\text { Maxwell, Ogden, } \quad \text { \& } \\
\text { Broadbridge, } 2010 .\end{array}$ \\
\hline
\end{tabular}

\subsection{Individual Innovativeness}

Although many variables influence how individuals react to innovation, individual innovativeness, which can be regarded as the most important one, has been a part of innovation distribution studies for a long time (Agarwal \& Prasad, 1998). The concept of innovativeness can be defined as differences among individuals that characterize how individuals react to new things. As an individual characteristic, individual innovativeness can be related to taking risks, being open new experiences or age (Goldsmith \& Foxall, 2003). Individual innovativeness is a factor that determines whether one individual accepts innovation before others (Agarwal \& Prasad, 1998). In this line, innovativeness can be defined as one individual's or other organizations' level of accepting a new idea relatively earlier than other members of the society (Rogers, 1983; Daft \& Marcic, 2011). Individuals react differently to a new idea, application or product due to their characteristics of individual innovativeness. Rogers (1983) categorizes individuals or other unit of adoption into five groups according to their level of innovativeness as follows: (1) innovators, (2) early adopters, (3) early majority, (4) late majority, and (5) laggards (Rogers, 1983).

According to Scott and Bruce (1994), innovation is a multi-level process which requires certain behaviors and actions in each of its levels. They described innovation as sectional activities where individuals can get involved in any level rather than an activity consisting of different and successive levels (Scott \& Bruce, 1994). From this perspective, innovative behavior can be approached as the activity of searching new ideas and solutions, development and application. The generation that one belongs, influences performing innovative behavior in line with age. According to Rogers (1963), innovators are younger than those who adopt innovation afterwards (Rogers, 1963). Then, factors such as technology, which are specific to generations, are seen. In a study focusing particularly on Generation Y, which is more involved in technology, it was found that other generations considered Generation Y different from themselves in terms of their creativity and innovation ability. They ranked Generation $\mathrm{Y}$ high for their ability to create and innovate (Moon, 2014).

A research company did a research on Generation Y in 2014 and found out that this generation consisted of individuals willing to innovate and preferring to work in the organizations encouraging innovative activities (Deloitte, 2014). In this context, the first hypothesis of the study is: 
Hypothesis 1: There is a significant difference between Generation $\mathrm{X}$ and Generation $\mathrm{Y}$ in terms of individual innovativeness.

Individual innovativeness is influenced by both individual characteristics and the characteristics of the social system the individual belongs to (Rogers, 1983). This study focuses on organizational learning orientation, one of those characteristics.

\subsection{Organizational Learning Orientation}

An important concept put forward in the 90s was Peter Senge's "learning organizations." This concept, then, enlightened various companies that accomplished evolutionary changes in the business world. Senge (1990) defined learning organization as an organization that continuously acquire information, unify and form this information with their activities by improving it, and thus aim to gain competitive advantage by achieving continuous improvement. Senge specifically focused on the importance of the concept of learning organizations by underlining organizations' non-learning problem, criticized the attitudes and activities of human resources in organizations and pointed out the significance of an organization where team learning was used effectively. Obviously, the premise of team learning is the human resource that forms the team and their desire to learn. However, organizational learning is an accumulation of individual learning processes and a key element placed in the structure, process and culture of the organization (Sağsan, 2009). At this point, the concept of learning orientation comes out in the literature. Learning orientation is defined as individual's interest and devotion to improve themselves (Gong, Huang, \& Farh, 2009). With the concept of learning orientation, it is focused on the individual dimension of the concepts of learning organizations or organizational learning. Sinkula et al (1997) investigated learning orientation on three dimensions, which are commitment to learning, shared vision/purpose and open-mindedness.

The relevant literature (Hurley \& Hult, 1998; Baker \& Sinkula, 1999, 2002; Calantone, Cavusgil, \& Zhao, 2002; Lee \& Tsai, 2005; Keskin, 2006; Lin, Peng, \& Kao, 2008; Jiménez-Jiménez \& Sanz-Valle, 2011) shows that there is a high correlation between learning orientation and organizational innovativeness. The common finding of those studies is that the outcome of innovation is significantly linked to the organization's effectiveness during the process of learning. Moreover, many studies have found that organization with an efficient learning process (learning-oriented) are more successful in innovating (Baker \& Sinkula, 2002). Individual or behavioral innovativeness, two overlapping concepts, is considered as a sub-dimension of organizational innovativeness (Dulger, Alpay, Yilmaz, \& Bodur, 2014). Accordingly, it would not be incorrect to assume that there is a relationship between organizational learning and individual innovativeness.

Hypothesis 2: There is a significant relationship between health professionals' perception of organizational learning and their level of innovativeness.

\section{The Study}

\subsection{Aim and Design}

This study aims to determine the innovativeness level of individuals working in health sector where innovation is highly important; to determine whether innovativeness level differs from one generation to another; and to investigate the relationship between individuals' level of innovativeness and their perception of whether the organization they work in have learning orientation. This is a quantitative study. The data were analyzed through factor, t-test and correlation analysis in line with the aims of the study.

\subsection{Sample/Participants, Data Collection and Limitations}

According to the data from 2013, there are 735.159 health professionals employed in 1.517 health institutions. 139.933 of those health professionals are employed in 550 private institutions (Ministry of Health, 2013). The data were gathered from health professionals employed in the private health institutions in the Black Sea Region. The questionnaires constructed in line with the aims of the study were handed out personally and collected after a while. The three private hospitals have 850 employers in total. 500 of those employers were included in the study; however, only 283 questionnaires were sent back due to reasons such as employers' shifts and their being on leave. 9 of those questionnaires were excluded from the study as some parts of them were incomplete. Thus, 274 questionnaires were included in the study. Questionnaire rate of return is $69.5 \%$, which is adequate for the study to be carried out (Altunışık, Coşkun, Bayraktaroğlu, \& Yıldırım, 2005).

The limitation of the study is that it was carried out with health professionals employed in three hospitals in the Black Sea Region because of cost and time constraints.

\subsection{Survey Instrument and Data Analysis}

In the study, "Individual Innovativeness Scale" was used, which was developed by Hurt, Joseph and Cook (1977) to determine health professionals' level of innovativeness and the innovation groups they belong to, and which was adopted into Turkish by Kılıçer and Odabaş1 (2010). The scale is known to be one of the four best scales for 
measuring innovativeness, which are Jackson Personality Inventory, Kirton Adaption-Innovation Inventory, NEO Personality Inventory and Innovativeness Scale (Goldsmith \& Foxall, 2003).

The five-point Likert scale consists of 20 items about individuals' characteristics. 12 of the scale items are positive ( 1 , $2,3,5,8,9,11,12,14,16,18$ and 19), and 8 of them are negative $(4,6,7,10,13,15,17$ and 20) statements. Innovativeness score is calculated by subtracting the total score gathered from the negative statements from the score gathered from the positive statements, and adding 42 points to that. The lowest score one can get in the scale is 14 , and the highest 94. Thus, those who get above 80 are "Innovators"; those who get between 69 and 80 are "Early Adopters"; those who get between 57 and 68 are "Early Majority"; those who get between 46 and 56 are "Late Majority"; and those who get below 46 are "Laggards" (Kıllıçer \& Odabaş1, 2010).

As for organizational learning orientation, the "learning orientation scale" was used, developed by (Sinkula, Baker, \& Noordewier, 1997). The scale has three sub-sections and 11 items. It was adapted to Turkish language for the study. Then, individual innovativeness scale and learning orientation scale were merged and one single questionnaire was created.

The analysis of the data was performed using SPSS 22.0 and the level of significance was accepted as 0.005 in the interpretation of the results. The construct validity was investigated via exploratory factor analysis.

\subsection{Validity and Reliability}

A high degree of internal consistency was observed for the Individual Innovativeness Scale (Cronbach's Alpha value of 0.792). According to the factor analyses carried out, the KMO and Bartlett value was found as 0.842 (Sig. 0.000). As seen in Table 2 and Figure 1, as a result of the factor analysis and Varimax orthogonal rotation, all of the 20 items of Individual Innovativeness Scale analyzed are gathered under 5 factors whose eigenvalue is higher than 1.0. The explained variance of those 5 factors is $57.531 \%$. In the light of the literature and properties of the items, these factors have been respectively named as follows; opinion-leadership, openness to experience, resistance to change, cautiousness and risk-taking.

Table 2. Individual innovativeness scale factor analysis results

\begin{tabular}{|c|c|}
\hline Factors & $\begin{array}{c}\text { Factor } \\
\text { Loadings }\end{array}$ \\
\hline \multicolumn{2}{|l|}{ Factor 1. Opinion Leadership } \\
\hline Item 8: I feel that I am an influential member of my peer group. &, 776 \\
\hline Item 9: I consider myself to be creative and original in my thinking and behavior. & ,724 \\
\hline Item 11: I am an inventive kind of person. & 668 \\
\hline Item 12: I enjoy taking part in the leadership responsibilities of the groups I belong to. & 677 \\
\hline Item 14: I find it stimulating to be original in my thinking and behavior & ,576 \\
\hline Item 18: I am receptive to new ideas. & ,559 \\
\hline \multicolumn{2}{|l|}{ Factor 2. Openness to experience } \\
\hline Item 1: My peers often ask me for advice or information & 635 \\
\hline Item 2: I enjoy trying out new ideas. & ,828 \\
\hline Item 3: I seek out new ways to do things. & 800 \\
\hline Item 5: I frequently improvise methods for solving a problem when an answer is not apparent &, 532 \\
\hline \multicolumn{2}{|l|}{ Factor 3. Resistance to change } \\
\hline Item 4: I am generally cautious about accepting new ideas. & ,740 \\
\hline Item 6: I am suspicious of new inventions and new ways of thinking. & ,742 \\
\hline $\begin{array}{l}\text { Item 7: I rarely trust new ideas until I can see whether the vast majority of people around me } \\
\text { accept them. }\end{array}$ & ,518 \\
\hline $\begin{array}{l}\text { Item 10: I am aware that I am usually one of the last people in my group to accept something } \\
\text { new. }\end{array}$ & ,583 \\
\hline $\begin{array}{l}\text { Item 13: I am reluctant about adopting new ways of doing things until I see them working for } \\
\text { people around me }\end{array}$ & ,571 \\
\hline Item 20: I often find myself skeptical of new ideas. & ,538 \\
\hline \multicolumn{2}{|l|}{ Factor 4: Cautiousness } \\
\hline Item 15: I tend to feel that the old way of living and doing things is the best way & 812 \\
\hline Item 17: I must see other people using new innovations before I will consider them & ,633 \\
\hline \multicolumn{2}{|l|}{ Factor 5: Risk-taking } \\
\hline Item 16: I am challenged by ambiguities and unsolved problems & ,798 \\
\hline Item 19: I am challenged by unanswered questions. &, 590 \\
\hline
\end{tabular}




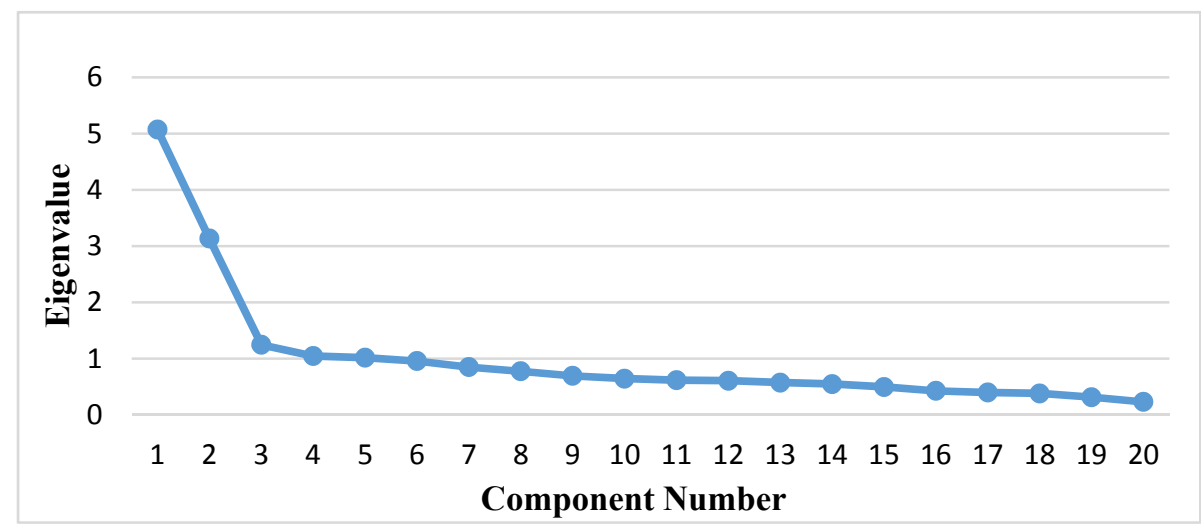

Figure 1. Scree plot of items

Learning Orientation Scale was analyzed for reliability, and the 11th item of the scale, "We rarely collectively question our own biases about the way we interpret customer information", was removed from the scale because of its low reliability alpha.

Analysis was performed with the rest of the items and the Cronbach Alpha value was found to be 0.879 . The exploratory factor analysis for learning orientation scale resulted in KMO and Bartlett value of 0.888 (Sig. 0.000). The dimensions of the scale showed a different distribution from the original scale: via varimax rotation technique, one single factor was determined consisting of 10 questions whose eigenvalues are 1 and above. The explanatory value of this one factor for total variance was determined to be $48.282 \%$.

Table 3. Learning orientation factor analysis results

\begin{tabular}{lc}
\hline \multicolumn{1}{c}{ Items } & $\begin{array}{c}\text { Factor } \\
\text { Loadings }\end{array}$ \\
\hline $\begin{array}{l}\text { Item 1:There is a commonality of purpose in my organization } \\
\text { Item 2:There is total agreement on our organizational vision across all levels, functions, and } \\
\text { divisions }\end{array}$ & 0,775 \\
\hline $\begin{array}{l}\text { Item 3:All employees are committed to the goals of this organization } \\
\text { Item 4: Learning in my organization is seen as a key commodity necessary to guarantee } \\
\text { organizational survival }\end{array}$ & 0,762 \\
\hline Item 5: The sense around here is that employee learning is an investment, not an expense & 0,739 \\
\hline $\begin{array}{l}\text { Item 6: Employees view themselves as partners in charting the direction of the organization } \\
\text { Item 7: Personnel in this enterprise realize that the very way they perceive the health }\end{array}$ & 0,730 \\
\hline $\begin{array}{l}\text { Item 8:Managers basically agree that our organization's ability to learn is the key to our } \\
\text { competitive advantage }\end{array}$ & 0,603 \\
\hline $\begin{array}{l}\text { Item 9: We are not afraid to reflect critically on the shared assumptions we have made about } \\
\text { customers }\end{array}$ & 0,555 \\
\hline \begin{tabular}{l} 
Item 10:The basic values of this organization include learning as the key to improvement \\
\hline
\end{tabular} & 0,543 \\
\hline
\end{tabular}

\subsection{Results}

\subsubsection{Sample Overview}

Table 4 shows descriptive statistics about participants. According to Table 4, majority of the participants (73.7\%) are females. This is due to the employment structure of the health sector. In terms of occupations, it is seen that physicians are mainly from Generation X and nurses are mainly from Generation Y. Also 38\% of participants are nurses, $27.4 \%$ are health/laboratory technicians, $24.4 \%$ other health professionals and $10.2 \%$ are physicians. While $82.8 \%$ of the participants are from Generation Y, $17.2 \%$ of them are from Generation X. $96 \%$ of the participants have worked in their present hospitals less than six years. $11.7 \%$ of the participants have worked in their present 
hospitals for 13 years or more. It is observed that the duration of employment in the hospitals is short. This could be due to the fact that workforce turnover rate in private health institutions is high and that the hospitals joined the study have a history of about ten years.

Table 4. Demographic characteristics of participants

\begin{tabular}{|c|c|c|c|c|}
\hline Variable & Category & Gen X (\%) & Gen Y (\%) & Total (\%) \\
\hline \multirow{3}{*}{ Gender } & Male & $25(53,2)$ & $177(78)$ & $202(73,7)$ \\
\hline & Female & $22(46,8)$ & $50(22)$ & $72(26,3)$ \\
\hline & Total & $47(100)$ & $227(100)$ & $274(100)$ \\
\hline \multirow[t]{5}{*}{ Profession } & Physician & $21(44,7)$ & $7(3,1)$ & $28(10,2)$ \\
\hline & Nurse & $10(21,3)$ & $94(41,4)$ & $104(38)$ \\
\hline & Technician & $4(8,5)$ & $71(31,3)$ & $75(27,4)$ \\
\hline & Other health pro. & $12(25,5)$ & $55(24,2)$ & $67(24,4)$ \\
\hline & Total & $47(100)$ & $227(100)$ & $274(100)$ \\
\hline \multirow{4}{*}{$\begin{array}{l}\text { Years of } \\
\text { experience in } \\
\text { the present } \\
\text { hospital }\end{array}$} & $1-3$ & $26(55,3)$ & $153(67,4)$ & $179(65,3)$ \\
\hline & $4-6$ & $17(36,2)$ & $67(29,5)$ & $84(30,7)$ \\
\hline & $7-9$ & $4(8,5)$ & $7(3,1)$ & $11(4)$ \\
\hline & Total & $47(100)$ & $227(100)$ & $274(100)$ \\
\hline \multirow{6}{*}{$\begin{array}{l}\text { Total years of } \\
\text { work } \\
\text { experience }\end{array}$} & $1-3$ & $5(10,6)$ & $117(51,5)$ & $122(44,5)$ \\
\hline & $4-6$ & $5(10,6)$ & $58(25,5)$ & $63(23)$ \\
\hline & $7-9$ & $4(8,6)$ & $36(15,9)$ & $40(14,6)$ \\
\hline & $10-12$ & $5(10,6)$ & $12(5,3)$ & $17(6,2)$ \\
\hline & 13 and $13+$ & $28(59,6)$ & $4(1,8)$ & $32(11,7)$ \\
\hline & Total & $47(100)$ & $227(100)$ & $274(100)$ \\
\hline
\end{tabular}

Table 5. Distribution of health professionals according to individual innovativeness categories

\begin{tabular}{lcc}
\hline $\begin{array}{l}\text { Categories of } \\
\text { innovativeness }\end{array}$ & $\begin{array}{c}\text { Frequency } \\
\text { (f) }\end{array}$ & $\begin{array}{c}\text { Percentage } \\
(\%)\end{array}$ \\
\hline Innovators & 16 & 5,8 \\
\hline Early Adopters & 72 & 26,3 \\
\hline Early Majority & 148 & 54,0 \\
\hline Late Majority & 32 & 11,7 \\
\hline Laggards & 6 & 2,2 \\
\hline Total & 274 & 100 \\
\hline
\end{tabular}

Participants were divided into categories after their individual innovativeness scores were calculated. According to this categorization, 54\% of the participants are "Early Majority" while only $2.2 \%$ of them are "Laggards".

Table 6. Innovativeness scores for professions

\begin{tabular}{lc}
\hline Professions & $\begin{array}{c}\text { Individual Innovativeness } \\
\text { Score }\end{array}$ \\
\hline Physician & 71,00 \\
\hline Nurse & 64,45 \\
\hline Technician & 63,46 \\
\hline Other health professionals & 65,34 \\
\hline
\end{tabular}

The analysis of individual innovativeness scores for participants' occupations shows that physicians are the most innovative group, which places them into "Early Adopters" group. Other employees are in "Early Majority" group and their scores are close to each other. 


\subsubsection{Comparison by Age-Generation}

According to Table 7, there is a significant difference between individual innovativeness scores when health professionals are grouped into Generation $\mathrm{X}$ and Generation $\mathrm{Y}$. It is seen from the mean score of individual innovativeness that members of Generation $\mathrm{X}$ are more innovative than those of Generation $\mathrm{Y}$. It is thought that this outcome is due to the fact that majority of the physicians that are more innovative are members of Generation X.

Table 7. T-test results for individual innovativeness scores of Generation X and Generation $Y$

\begin{tabular}{|c|c|c|c|c|c|c|}
\hline \multirow[t]{2}{*}{ Groups } & \multirow{2}{*}{$\begin{array}{c}\text { Average } \\
\text { Individual } \\
\text { Innovativeness } \\
\text { Score } \\
\end{array}$} & \multirow{2}{*}{$\begin{array}{l}\text { Standard } \\
\text { deviation }\end{array}$} & \multicolumn{2}{|c|}{ Levene's Test } & \multirow[t]{2}{*}{$\mathbf{t}$} & \multirow{2}{*}{$\begin{array}{l}\text { Sig. (two } \\
\text { tailed) }\end{array}$} \\
\hline & & & $\mathrm{F}$ & Sig & & \\
\hline Generation Y & 64,10 & 8,797 & \multirow{2}{*}{0,11} & \multirow{2}{*}{0,915} & \multirow{2}{*}{$-4,030$} & \multirow{2}{*}{0,000} \\
\hline Generation $\mathbf{X}$ & 69,74 & 8,443 & & & & \\
\hline
\end{tabular}

Table 8. T-test results for sub-factors' score of individual innovativeness scale for Generation X and Generation Y

\begin{tabular}{|c|c|c|c|c|c|c|c|c|}
\hline & \multirow[t]{2}{*}{ Groups } & \multirow[t]{2}{*}{ Mean } & \multirow{2}{*}{$\begin{array}{l}\text { Standard } \\
\text { deviation }\end{array}$} & & \multicolumn{2}{|c|}{ Levene's Test } & \multirow[t]{2}{*}{$\mathbf{t}$} & \multirow{2}{*}{$\begin{array}{c}\text { Sig. } \\
\text { (2-tailed) }\end{array}$} \\
\hline & & & & & $\mathrm{F}$ & Sig & & \\
\hline \multirow{4}{*}{$\begin{array}{l}\text { Factor Score 1: } \\
\text { Opinion } \\
\text { Leadership }\end{array}$} & $\mathrm{Y}$ & $-0,053$ & 1,027 & Equal variances & 3,578 & 0,06 & $-1,944$ & 0,053 \\
\hline & & 2 & & assumed & & & & \\
\hline & $\mathrm{X}$ & 0,256 & 0,819 & Equal variances & & & $-2,253$ & 0,027 \\
\hline & & 8 & & not assumed & & & & \\
\hline \multirow{4}{*}{$\begin{array}{l}\text { Factor Score 2: } \\
\text { Openness to } \\
\text { experience }\end{array}$} & $\mathrm{Y}$ & $-0,034$ & 1,041 & Equal variances & 4,876 & 0,028 & $-1,251$ & 0,212 \\
\hline & & 4 & & assumed & & & & \\
\hline & $\mathrm{X}$ & 0,165 & 0,754 & Equal variances & & & $-1,541$ & 0,127 \\
\hline & & 9 & & not assumed & & & & \\
\hline \multirow{4}{*}{$\begin{array}{l}\text { Factor Score 3: } \\
\text { Resistance to } \\
\text { change }\end{array}$} & Y & $-0,072$ & 0,991 & Equal variances & 0,061 & 0,805 & $-2,672$ & 0,008 \\
\hline & & 6 & & assumed & & & & \\
\hline & $\mathrm{X}$ & 0,350 & 0,977 & Equal variances & & & $-2,697$ & 0,009 \\
\hline & & 9 & & not assumed & & & & \\
\hline \multirow{4}{*}{$\begin{array}{l}\text { Factor Score 4: } \\
\text { Cautiousness }\end{array}$} & Y & 0,003 & 0,980 & Equal variances & 0,612 & 0,435 & 0,123 & 0,902 \\
\hline & & 4 & & assumed & & & & \\
\hline & $\mathrm{X}$ & $-0,016$ & 1,099 & Equal variances & & & 0,114 & 0,909 \\
\hline & & 4 & & not assumed & & & & \\
\hline \multirow{4}{*}{$\begin{array}{l}\text { Factor Score 5: } \\
\text { Risk-taking }\end{array}$} & Y & $-0,066$ & 1,021 & Equal variances & 2,257 & 0,134 & $-2,426$ & 0,016 \\
\hline & & 1 & & assumed & & & & \\
\hline & $X$ & 0,319 & 0,825 & Equal variances & & & $-2,790$ & 0,007 \\
\hline & & 3 & & not assumed & & & & \\
\hline
\end{tabular}

The analysis of the answers given by Generation $\mathrm{X}$ and Generation $\mathrm{Y}$ to sub-factors of Individual Innovativeness Scale shows that there is a significant difference in the confidence interval of $95 \%$ in the factors of "resistance to change" and "risk taking." There is no significant difference between generations in the sub-factors of "opinion-leadership", openness to experience "and "cautiousness". 
Table 9. Relationship between individual innovativeness score and organizational learning

\begin{tabular}{lcc}
\hline & & $\begin{array}{c}\text { Perception of Organizational } \\
\text { Learning Orientation }\end{array}$ \\
\hline Individual innovativeness & Pearson Correlation & $0,187 * *$ \\
\cline { 2 - 3 } Score & Sig. (2-tailed) & 0,002 \\
\hline$* * \mathbf{P}<\mathbf{0 , 0 1}$ & & \\
\end{tabular}

As seen in Table 9, there is a low-level but significant and positive relationship between individual innovativeness score and organizational learning.

Table 10. Relationship among the sub-factors of individual innovativeness scale

\begin{tabular}{|c|c|c|c|c|c|c|}
\hline Factors & & $\begin{array}{c}\text { Opinion } \\
\text { Leadership }\end{array}$ & $\begin{array}{c}\text { Openness } \\
\text { to } \\
\text { experience }\end{array}$ & $\begin{array}{l}\text { Resistance } \\
\text { to change }\end{array}$ & Cautiousness & $\begin{array}{c}\text { Risk-tak } \\
\text { ing }\end{array}$ \\
\hline \multirow{2}{*}{$\begin{array}{l}\text { Opinion } \\
\text { Leadership }\end{array}$} & Pearson Correlation & 1 & $0,646 * *$ & 0,067 & 0,001 & $0,431 * *$ \\
\hline & Sig. (2-tailed) & & 0,000 & 0,271 & 0,987 & 0,000 \\
\hline \multirow{2}{*}{$\begin{array}{l}\text { Openness to } \\
\text { experience }\end{array}$} & Pearson Correlation & & 1 & $-0,021$ & $-0,063$ & $0,327 * *$ \\
\hline & Sig. (2-tailed) & & & 0,729 & 0,300 & 0,000 \\
\hline \multirow{2}{*}{$\begin{array}{l}\text { Resistance to } \\
\text { change }\end{array}$} & Pearson Correlation & & & 1 & $0,474 * *$ & $-0,027$ \\
\hline & Sig. (2-tailed) & & & & 0,000 & 0,653 \\
\hline \multirow[t]{2}{*}{ Cautiousness } & Pearson Correlation & & & & 1 & $-0,049$ \\
\hline & Sig. (2-tailed) & & & & & 0,420 \\
\hline \multirow[t]{2}{*}{ Risk-taking } & Pearson Correlation & & & & & 1 \\
\hline & Sig. (2-tailed) & & & & & \\
\hline
\end{tabular}

Table 10 demonstrates that there is a medium-level positive relationship among "opinion-leadership", "openness to experience" and "risk-taking" sub-factors of Individual Innovativeness Scale. Meanwhile, the factors of "resistance to change" and "cautiousness" also have medium-level, significant and positive relationship between each other.

\section{Discussion}

According to Drucker (1993), innovation is remarkably important for gaining and maintaining competitive advantage in contemporary economies (Drucker, 1993). This is true for not only production industry but also service industry. In the developed economies, 7\% of Gross National Product (GNP) is products and services coming from health sector, and the employment created within this sector is $10 \%$. It is estimated that the rate of total health expenses to GNP will increase to $16 \%$ by 2020 . Health sector, growing rapidly, is one of the greatest sources and users of innovative technologies (TÜSİAD, 2011). In this sense, individuals' innovativeness becomes an important factor. Individuals with high score of innovativeness play role in both creation and effective use of innovation. One of the most credited classifications regarding innovation level belongs to Roger (1983), which consists of five innovation levels: Early Adopters, Early Majority, Late Majority and Laggards. More than half of the participants in this study (54\%) are in Early Majority group. Those in this group have adopted new ideas slightly earlier than an average member of the social system they belong to. They prefer to consult to others before they adopt any ideas (Rogers, 1983).

Generation individuals belong to is thought to be one of the factors influencing their innovativeness level. That is why, this study investigated whether there was a significant relationship between innovativeness levels between generations. Initially it was assumed that members of Generation $\mathrm{Y}$ would be more innovative since they were younger and more inclined towards technology; however, the analysis of the data showed that there is a significant difference of innovativeness levels between the two generations and that members of Generation $\mathrm{X}$ are more 
innovative. Though it looks controversial, this outcome is thought to have resulted from the fact that almost all of the members of Generation X who participated in the study are physicians because they are one of the highest-educated professional groups within their society and institutions. Accordingly, it can be noted from the point of health sector that professional groups are more effective in innovative professional behavior, rather than generational dimension. On the other hand, this study also indicates that the existing innovative professional behavior of individuals who have reached a certain level of maturity in professional life can be higher than those individuals that are new in the profession and have less experience. In terms of generation theories, Generation $\mathrm{Y}$, assumed to be more innovative, may demonstrate less innovative characteristic considering factors such as working conditions, professional life and experience. These results highlight that issues regarding organizational behavior should not be discussed merely from a generational perspective, rather they should be approached from a multi-dimensional perspective.

Another issue investigated in the study was whether there was a relationship between individuals' perception of their institutions' learning orientation and their innovativeness level. It was initially assumed that individuals' belief that their institutions had learning orientation would be an encouraging factor for innovation and would increase innovativeness. The study shows that there is a significant and positive relationship between those two variables. The results are consistent with similar studies (Lee \& Tsai, 2005; Keskin, 2006; Jiménez-Jiménez \& Sanz-Valle, 2011). This can be considered to have resulted from the close relationship between innovativeness, individual and organizational learning. Indeed innovativeness is a product of an effective individual and organizational learning process.

This study was conducted in health institutions, which are bound to provide individuals with more innovative and more quality services. The results show that younger generations may not always be more innovative. The results of this study need to be compared with future studies. Future studies carried out in various sectors and more institutions will show these two generations' understanding of innovation.

\section{References}

Agarwal, R., \& Prasad, J. (1998). A conceptual and operational definition of personal innovativeness in the domain of information technology. Information Systems Research, 9(2), 204-215. http://dx.doi.org/10.1287/isre.9.2.204

Altunışık, R., Coşkun, R., Bayraktaroğlu, S., \& Yıldırım, E. (2005). Sosyal bilimlerde araştirma yöntemleri: SPSS uygulamall (Research Methods in Social Sciences: Applied Statistics with SPSS). Adapazarı: Sakarya Kitabevi.

Baker, W. E., \& Sinkula, J. M. (1999). The synergistic effect of market orientation and learning orientation on organizational performance. Journal of the Academy of Marketing Science, 27(4), 411-427. http://dx.doi.org/10.1177/0092070399274002.

Baker, W. E., \& Sinkula, J. M. (2002). Market orientation, learning orientation and product innovation: Delving into the organization's black box. Journal of Market-Focused Management, 5(1), 5-23. http://dx.doi.org/10.1023/A:1012543911149

Benson, J., \& Brown, M. (2011). Generations at work: Are there differences and do they matter? The International Journal of Human Resource Management, 22(9), 1843-1865. http://dx.doi.org/10.1080/09585192.2011.573966.

Calantone, R. J., Cavusgil, S., \& Zhao, Y. (2002). Learning orientation, firm innovation capability, and firm performance. Industrial Marketing Management, 31(6), 515-524. http://dx.doi.org/10.1016/S0019-8501(01)00203-6.

Cogin, J. (2012). Are generational differences in work values fact or fiction? Multi-country evidence and implications. The International Journal of Human Resource Management, 23(11), 2268-2294. http://dx.doi.org/10.1080/09585192.2011.610967

Daft, R., \& Marcic, D. (2011). Understanding management. Mason: South Western.

Deloitte. (2014). The Deloitte Millennial Survey - Executive summary. Deloitte.

Dixon, G., Mercado, A., \& Knowles, B. (2013). Followers and generations in the workplace. Engineering Management Journal, 25(4), 62-72. http://dx.doi.org/10.4271/2011-01-0080

Drucker, P. F. (1993). Innovation and entrepreneurship. New York: HarperCollins.

Dulger, M., Alpay, G., Yilmaz, C., \& Bodur, M. (2014). How do learning orientation and strategy yield innovativeness and superior firm performance? South African Journal of Business Management, 45(2), 35-50.

Giancola, F. (2006). The generation gap: More myth than reality. Human Resource Planning, 29(4), 32-37. 
Goldsmith, R. E., \& Foxall, G. R. (2003). The measurement of innovativeness. In L. V. Shavinina (Ed.), The International Handbook on Innovation (s. 321-330). Oxford: Elsevier.

Gong, Y., Huang, J.-C., \& Farh, J.-L. (2009). Employee learning orientation, transformational leadership, and employee creativity: The mediating role of employee creative self-efficacy. Academy of Management Journal, 52(4), 765-778. http://dx.doi.org/10.5465/AMJ.2009.43670890

Guillot-Soulez, C., \& Soulez, S. (2014). On the heterogeneity of Generation Y job preferences. Employee Relations, 36(4), 319-332. http://dx.doi.org/10.1108/ER-07-2013-0073.

Gürsoy, D., Maier, T. A., \& Chi, C. G. (2008). Generational differences: An examination of work values and generational gaps in the hospitality workforce. International Journal of Hospitality Management, 27(3), 448458. http://dx.doi.org/10.1016/j.ijhm.2007.11.002

Hurley, R. F., \& Hult, G. T. (1998). Innovation, market orientation, and organizational learning: An integration and empirical examination. Journal of Marketing, 62, 42-54.

Hurt, H. T., Joseph, K., \& Cook, C. D. (1977). Scales for the measurement of innovativeness. Human Communication Research, 4(1), 58-65. http://dx.doi.org/10.1111/j.1468-2958.1977.tb00597.x

Jiménez-Jiménez, D., \& Sanz-Valle, R. (2011). Innovation, organizational learning, and performance. Journal of Business Research, 64(4), 408-417. http://dx.doi.org/10.1016/j.jbusres.2010.09.010

Johnson, M., \& Johnson, L. (2010). Generations, Inc. New York: AMACOM.

Kertzer, D. L. (1983). Generation as a sociological problem. Annual Review Sociology, 9, 125-149. http://dx.doi.org/10.1146/annurev.so.09.080183.001013

Keskin, H. (2006). Market orientation, learning orientation, and innovation capabilities in SMEs: An extended model. European Journal of Innovation Management, 9(4), 396-417. http://dx.doi.org/10.1108/14601060610707849

Kılıçer, K., \& Odabaşı, H. F. (2010). Bireysel yenilikçilik ölçeği (BYÖ): Türkçeye uyarlama,geçerlik ve güvenirlik çalışması (Individual Innovativeness Scale (IS): The study of adaptation to Turkish, validity and reliability). Hacettepe Üniversitesi Eğitim Fakültesi Dergisi, 38, 150-164.

Kupperschmidt, B. R. (2000). Multigeneration employees: Strategies for effective management. The Health Care Manager, 19(1), 65-76. http://dx.doi.org/10.1097/00126450-200019010-00011

Lee, T.-S., \& Tsai, H.-J. (2005). The effects of business operation mode on market orientation, learning orientation and innovativeness. Industrial Management \& Data Systems, 105(3), 325-348. http://dx.doi.org/10.1108/02635570510590147

Lin, C.-H., Peng, C.-H., \& Kao, D. T. (2008). The innovativeness effect of market orientation and learning orientation on business performance. International Journal of Manpower, 29(8), 752-772. http://dx.doi.org/10.1108/01437720810919332

Lyons, S. T., Schweitzer, L., \& Ng, E. S. (2015). How have careers changed? An investigation of changing career patterns across four generations. Journal of Managerial Psychology, 30(1), 8-21. http://dx.doi.org/10.1108/13620431211255824.

Meriac, J. P., Woehr, D. J., \& Banister, C. (2010). Generational differences in work ethic: An examination of measurement equivalence across three cohorts. Journal of Business and Psychology, 25(2), 315-324. http://dx.doi.org/10.1007/s10869-010-9164-7

Ministry of Health. (2013). Sağlık İstatistikleri Ytllĭğ (Health Statistics Yearbook). Ankara: SAGEM.

Montana, P. J., \& Petit, F. (2008). Motivating Generation X and Y on the job and preparing Z. Global Journal of Business Research, 2(2), 139-148.

Moon, T. M. (2014). Mentoring the next generation for innovation in today's organization. Journal of Strategic Leadership, 23-35.

Parry, E., \& Urwin, P. (2011). Generational differences in work values: A review of theory and evidence. International Journal of Management Reviews, 13, 79-96. http://dx.doi.org/10.1111/j.1468-2370.2010.00285.x

Pilcher, J. (1994). Mannheim's sociology of generations: An undervalued legacy. British Journal of Sociology, 45(3), 481-495. 
Puybaraud, M., Russell, S., MsEwan, A., \& Leussink, E. (2010). Generation Y and the workplace annual report 2010. London: Johnson Controls.

Rogers, E. M. (1963). What are innovators like? Theory into Practice, 2(5), 252-256. http://dx.doi.org/10.1080/00405846309541872.

Rogers, E. M. (1983). Diffusion of innovations (3rd ed.). New York: The Free Press.

Sağsan, M. (2009). Örgütsel Öğrenememezliğe karşi bilginin yönetilebilirliği (The barriers to organizational learning vs. Knowledge Management). In K. Varoğlu, \& N. Basım (Eds.), Örgütlerde değişim ve öğrenme (Organizational change and learning) (s. 93-120). Ankara: Siyasal Kitabevi.

Sayers, R. (2007). The right staff from X to Y. Library Management, 28(8/9), 474-487. http://dx.doi.org/10.1108/01435120710837765

Schullery, N. M. (2013). Workplace engagement and generational differences in values. Business and Professional Communication Quarterly, 76(2), 252-265. http://dx.doi.org/10.1177/1080569913476543.

Schultz, C., Zippel-Schultz, B., \& Salomo, S. (2012). Hospital innovation portfolios: Key determinants of size and innovativeness. Health Care Manage Review, 37(2), 132-143. http://dx.doi.org/10.1097/HMR.0b013e31822aa41e

Scott, S. G., \& Bruce, R. A. (1994). Determinants of innovative behavior: A path model of individual innovation in the workplace. Academy of Management Joumal, 37(3), 580-607. http://dx.doi.org/10.2307/256701

Senge, P. M. (1990). The fifth discipline: The art \& practice of the learning organization. New York: Doubleday.

Sinkula, J. M., Baker, W. E., \& Noordewier, T. (1997). A framework for market-based organizational learning: Linking values, knowledge, and behavior. Journal of the Academy of Marketing Science, 25(4), 305-318. http://dx.doi.org/10.1177/0092070397254003.

Smola, K. W., \& Sutton, C. D. (2002). Generational differences: revisiting generational work values for the new millennium. Journal of Organizational Behavior, 23(4), 363-382. http://dx.doi.org/10.1002/job.147

TÜIK. (2013). Adrese dayalı nüfus kayıt sistemi (ADNKS) Veri Tabanı (Address based population registration system data base). Haziran 24, 2014 tarihinde Türkiye İstatistik Kurumu (Turkish Statistical Institute). Retrieved from http://tuikapp.tuik.gov.tr/adnksdagitapp/adnks.zul

TÜİK. (2014, April). İsgücü istatistikleri (Labor statistics). Ağustos 13, 2014 tarihinde Türkiye İstatistik Kurumu (Turkish Statistical Institute). Retrieved from http://tuikapp.tuik.gov.tr/Dagitim_uyg/?kn=72\&locale=tr

TÜSİAD. (2011). Türkiye'nin Avrupa Birliği'ne üyelik sürecinde sağllkta inovasyon (Innovation in the health sector in Turkey on Its Way to EU membership). İstanbul: TÜSİAD.

Twenge, J. M. (2010). A review of the empirical evidence on generational differences in work attitudes. Journal of Business \& Psychology, 25, 201-210. http://dx.doi.org/10.1007/s10869-010-9165-6

Young, S. J., Sturts, J. R., Ross, C. M., \& Kim, K. T. (2013). Generational differences and job satisfaction in leisure services. Managing Leisure, 18(2), 152-170. http://dx.doi.org/10.1080/13606719.2013.752213

Zemke, R., Raines, C., \& Filipczak, B. (2013). Generations at work (2nd ed.). New York: AMACOM. 